\title{
Clean and Green with Deepening Shadows? A Non-Complacent View of Corruption in New Zealand
}

\author{
Robert Gregory \\ Adjunct Professor of Politics, School of Government, Victoria University of Wellington, \\ New Zealand \\ Email: bob.gregory@vuw.ac.nz
}

\author{
Dan Zirker \\ Professor of Political Science, University of Waikato, New Zealand \\ Email: dzirker@waikato.ac.nz
}

\begin{abstract}
Paper presented to the $8^{\text {th }}$ Annual Conference of The Asian Studies Association of Hong Kong, The Hong Kong Institute of Education, Tai Po, 8-9 March 2013
\end{abstract}

\begin{abstract}
:
New Zealand has long been regarded as a country with little or no governmental corruption. In recent times it has been ranked consistently as one of the five least corrupt countries in the world, on Transparency International's (TI) Corruption Perceptions Index (CPI). In 2009 and 2011 it was ranked as the single most corruption-free country on the CPI, and in 2012 it shared first place with Denmark and Finland. This paper examines the reasons why historically New Zealand has been largely free of governmental corruption, using widely accepted definitions of what constitutes corrupt behaviour. It goes on to argue that, at least by its own normal standards, the country might now be more susceptible to corruption, for a variety of reasons, in both the public and private sectors, and that more political and administrative attention may need to be paid to this issue. The paper discusses New Zealand's surprising tardiness in ratifying the United Nations Convention against Corruption, an apparent reluctance that leaves the country sitting alongside other non-ratifying countries which have endemic levels of corruption in all its forms. In this context, the paper also notes some international dissatisfaction with New Zealand's anti-money laundering legislation, enacted in 2009.
\end{abstract}

Acknowledgement - the authors would like to thank our New Zealand colleagues, Peter Jones and John Martin, for their valuable contributions to our discussion in the historical section. The usual disclaimer applies. 


\section{Introduction}

New Zealand has a long-standing reputation as a country in which there is little or no governmental corruption. A seldom asked question is: why is this so? In fact, the reasons as to why any country has high or low levels of corruption are seldom self-evident, and usually beg closer examination. There are several main factors, discussed below, which provide an answer to this question in New Zealand's case. However, circumstances change, and there is no guarantee that either corruption generally or governmental corruption specifically will not become significant problems in New Zealand. There are some signs, which are examined here, which suggest that while relative to other countries New Zealand continues to enjoy very low levels of corruption, nevertheless there is no room for national complacency on this issue, certainly not if concern is gauged against the country's own high standards. The country's strong international reputation in this regard, which in itself is an important national asset, could be subjected to significantly closer scrutiny in the years ahead.

\section{New Zealand and the Corruptions Perceptions Index (CPI)}

New Zealand has long been rated by Transparency International's Corruption Perception Index (CPI) as one of the six least corrupt countries in the world. It was rated as first, or first equal (that is, perceived as the least corrupt or equally least corrupt country in the world), in 2006, 2007, 2008, 2009 and 2010, sitting alone atop the rankings in 2009 and 2011, and sharing the top position again (with Denmark and Finland) in 2012. New Zealand's image as a country in which there is very little, if any, governmental corruption is all the more impressive because of the country's bicultural and multi-cultural character, as charges and counter-charges of corruption are thought to be far more common in multi-cultural settings. The CPI model largely avoids rapid shifts in rankings, and may even carry with it a propensity to serve as a self-fulfilling factor. And one of the founding members of TI has argued that the CPI, following the advent in 2003 of the United Nations 
Convention against Corruption, should no longer be published in its present form because it tends to undermine the efforts of reformers (Galtung, 2006). Nevertheless, Iceland, which ranked first equal in 2006 (with Finland and New Zealand) but later experienced a national banking collapse, had dropped to $13^{\text {th }}$ by 2011 (but rising to $11^{\text {th }}$ in 2012), thus demonstrating that prevailing perceptions of a country's national integrity and honesty can indeed change quite rapidly (Zirker, Gregory and Scrimgeour, 2012).

\section{Why has New Zealand historically been largely corruption-free?}

Among the most difficult research questions which arise out of the CPI are those which seek to explain why some countries differ in their levels of governmental and societal corruption. At one level, such answers are not far to seek, on the face of it at least, if researchers want to know why, for example, Denmark or New Zealand experience much lower levels of corruption than, say, Vietnam or the Philippines, or Mongolia, or Somalia. Conventional responses in such cases would probably refer to data such as that provided by the Worldwide Governance Indicators (WGI), which place strong emphasis on factors like the rule of law, regulatory quality, voice and accountability, not to mention the control of corruption itself. At the risk of being somewhat tautological, the latter WGI dimension - control of corruption - suggests that corruption is low because it is well controlled. Such a focus on the control of corruption is of crucial importance, and much of the comparative literature on corruption argues the importance of institutionalised principal-agent relations, notably a well-resourced, independent and impartial anti-corruption agency driven by high levels of political will, the rule of law, a similarly independent and impartial judiciary, and so on, in the successful containment of corruption (Quah, 2003, 2010, 2011). However, these principal-agent interpretations, as important as they are, often do not tell the full story. In focusing largely on political dimensions they tend to overlook the more dynamic historical, 
cultural and social factors which often are at least as, if not more, important in understanding why some countries have lower levels of corruption than others. In fact, each country has its own particular narrative. A good example of such a narrative is the following, offered as a partial explanation of the rise in corruption in Spain around the mid-2000s:

...in the years following Franco's death (1975) up to the early 1990s, the focus of the builders of the new local and regional politico-administrative structures - that is to say, mainly the Socialists - was on weakening the administrative controls on local governments inherited from the dictatorship...The building of a public administration for the new democracy was largely neglected. This shortcoming was accompanied by an outsized interpretation by the Constitutional Court and others of the newly acquired municipal autonomy bestowed uniformly on all municipalities by the 1978 constitution... These two elements (large autonomy and weak control) led to a very weak checks and balances system.... and to the assumption that at the local and regional government levels, a politician winning an election had carte blanche, an unrestricted power to do as he saw fit (Cardona, 2013: 95).

For the purposes of comparison, it is not difficult to provide, for example, a plausible explanation as to why Somalia has much more corruption than Denmark, an explanation that will owe much more to historical and cultural factors than to principal-agent differences. Conversely, historical and cultural factors are likely to be less important than principal-agent approaches in explaining why two countries, Denmark and New Zealand, are consistently ranked on the CPI as being largely corruption-free. In comparisons like this, cultural and historical factors seem less important than the fact that both countries are highly rated on the WGI.

In such cases comparative investigation into cultural and historical elements seems irrelevant. But is it? What about, for example, Australia and New Zealand, two countries with similar cultures and heritages (the 'ANZAC' tradition), and both Westminster-styled parliamentary democracies, but which have continued to display consistently different rankings on the CPI, with New Zealand always significantly higher than Australia? ${ }^{1}$ In the 13 years from 2000 to 2012, New Zealand's lowest position on the CPI was third or third equal, while from 2006 to 2012 it was either first or first equal. On the other hand, Australia's lowest ranking was $13^{\text {th }}$, in 2000 , and its highest was seventh equal, in 2012. New Zealand's average CPI score during this period was 9.42, while 
Australia's was 8.65 - a substantial difference in perceived levels of corruption within these two countries with such similar backgrounds. How can this difference be explained?

Some obvious factors immediately suggest themselves as plausible explanations: for example, early European Australia was to a large extent a penal colony, whereas New Zealand was a British settler society; and Australian political culture never embraced egalitarian ideals, as did New Zealand's - whereas Australia, perhaps because of resentment of the English, developed its selfimage along individualist and competitive American lines. By contrast, New Zealanders generally looked fondly on Britain as 'home', and were one of the first countries to develop a welfare state. Moreover, as a federal system, Australia experienced political corruption reminiscent of American 'Tammany Hall' politics, especially in New South Wales and Victoria in the earlier half of the $20^{\text {th }}$ century (see Griffin, 1990, 2004). While this form of politics was not completely absent in New Zealand, it was much less common. However, while it might seem plausible — on the face of it — to suggest that Australia's $19^{\text {th }}$ century history as a British penal colony gave rise to non-compliance norms and values (presumably because a higher propensity for unlawful behaviour has been passed down through Australian generations), it would be drawing a very long bow to conclude that this helps to explain why there have been higher overall levels of corruption, or at least the perceptions thereof, in Australia than in New Zealand. Ironically, the central figure in New Zealand's early colonisation — the director of the New Zealand Company, Edward Gibbon Wakefield — had in 1827 himself been sentenced to three years in London's Newgate prison on abduction charges (Temple, 2002).

We will sketch some reasons as to why New Zealand, in its own terms, has enjoyed for so long a reputation for having very low levels of corruption, especially in government. There are two interrelated issues: New Zealand's reputation as being a country with very low levels of corruption, on the one hand, and the reality of corruption in New Zealand, on the other. Clearly, most of the available evidence suggests that the reputation quite closely matches the reality: there are unlikely 
to be expanding black seams of governmental venality occluded behind the country's 'clean and green' and corruption-free image. Accepting that proposition then, we find that any explanation of why this is the case must take the form of some story, a narrative that blends historical, social, political and cultural dimensions into a reasonably coherent and plausible explanation. The alternative - a rigorous scientific collation and interpretation of hard data, producing a conclusive result — is almost certainly beyond practical reach.

We suggest that perhaps the most important factor has been New Zealand's strong egalitarian ethos that underwrote one of the world's first welfare states (King, 2003; Lipson, 1948; Sutch, 1969). ${ }^{2}$ Most early New Zealand settlers came in the mid- $19^{\text {th }}$ century from a Britain in which they themselves were oppressed by class divisions. Although privilege did emerge, largely in the form of 'squatters' who acquired large land-holdings, the emergent political culture was resistant to such acquisition, and by the turn of the $20^{\text {th }}$ century it had broken down. As Fischer (2012) has demonstrated in his comprehensive historical comparison between New Zealand and the United States, New Zealanders have traditionally been far more committed to fairness rather than freedom, while in America the converse has generally been true. In fact, by 1930 the news media in America tended to characterise New Zealand's carefully regulated emphasis on fairness in society as an outrageous denial of freedom, even the hallmark of an emerging fascist state. In an article by a 'special correspondent', entitled 'Life in New Zealand Now Ruled by Decree; Even ChickenRaising Is Regulated by State', the New York Times reported that:

The nooks and corners that [New Zealand] has explored in its Fascist rule may be seen from the fact that it has forbidden the building of any more movie theatres without permission, on the ground that there are already more than enough, has refused to issue any more leases to coal operators to mine on State lands because of over-production of coal, and has even determined to register and control all persons who own ten hens or more and sell eggs....Slowly this democracy is turning into a Fascist State. When it completes the cycle it will do so with a thoroughness which will fill the Black Shirts with envy (New York Times, December 11, 1930: E4).

As two commentators later said about the New Zealand government's economic stabilization programme, during the Second World War, '...the government was engaged in an elaborate piece 
of social engineering. Ministers were attempting to construct a wartime economy that would treat all sections as fairly as possible' (Bassett and King, 2000: 201). Another has called the country's egalitarian ethos 'a society of fair shares' (Roberts, 1978: 73).

Nevertheless, any relationship between egalitarianism — especially as 'fairness' — and corruption itself awaits adequate explanation (Gregory, 2003). Relatively low levels of government corruption are also seen in jurisdictions like Singapore and Hong Kong, which are by no means egalitarian, and in New Zealand itself, where income inequality has increased almost dramatically since the economic reforms of the late 1980s and early 1990s, the country still ranks at the top of the CPI. ${ }^{3}$ On the other hand, Denmark, Norway and Sweden, all at or near the top of the CPI, are countries with historically strong egalitarian cultures, and all today have Gini co-efficient scores much lower than New Zealand's, as has Australia. All these countries (and Hong Kong) score well on the Worldwide Governance Indicators, however, confirming that lower levels of corruption are a function of factors other than just egalitarianism. In his commentary on an analysis of a recent increase in corruption in Spain, Cardona (2013: 95) said that, 'I could not agree more with the concluding remarks of the article: "institutional designs and procedures that promote accountability and transparency in government, to the extent that they prevent corruption, may help diminish disaffection and promote compliance with laws and social norms." For the sake of completeness, I would only add that if policies also promote equality, the propensity to seek corrupt deals dwindles.' Again though, the question is-why? It might be because egalitarianism per se, that is, income equality, does not keep corruption at minimal levels, but that egalitarianism itself reflects a social ethos which places a relatively low emphasis on acquisitive and competitive values, especially those which define social status overwhelmingly as a function of wealth.

Another important and allied factor in New Zealand was the strong Calvinist culture that the country's British settlers brought with them, especially from Scotland, and which endured at least until the middle of the $20^{\text {th }}$ century. Values of thrift, hard work, and social cohesion were central to 
the country's development as 'God's Own Country' (or 'Godzone', as it is more cynically referred to today), a relatively prosperous, modern mixed economy, a welfare state built on land-based primary industry. Throughout most of the $20^{\text {th }}$ century, until the loss of primary markets, and the oil shocks in the 1970s, New Zealand's economic policies were deeply interwoven with its egalitarian social structure. These policies embodied the key objectives of full employment, financial stability, favourable terms of trade, and high productivity.

Further, New Zealand is a small country - today with a population of 4.45 million. As an island nation in the south Pacific, it has also been largely 'quarantined' from international influences that might otherwise have threatened to strain its social fabric. At least until Māori migration from rural to urban areas from the 1950s onwards, the rapid rise in Pacific Island immigration from about the same time, and the rapid increase in Asian immigrants from the 1980s, the country was dominated by European New Zealanders, fostering at least the illusion of a homogenous culture and society.

Especially during the decades when New Zealand was even less populous than it is today, urban and provincial communities enjoyed high levels of social capital, reciprocal bonds of collective cooperation and high levels of interpersonal trust. Thorstein Veblen's 'conspicuous consumption' was in these times scarcely apparent in New Zealand, not because high levels of individual and family wealth did not exist, but because strong social norms and expectations ensured that it was seldom flaunted. Social 'respectability' was highly valued and most people were wary about engaging in any form of behaviour which, if exposed to public scrutiny, would result in a loss of individual or family reputation. In many ways, therefore, the social and political climate in New Zealand was for a long time highly conformist, indeed in many ways stifling; but at the same time it was not an environment encouraging of those with corrupt intent. In short, New Zealand was largely a country of innocence, straight-laced, rather naïve and unsophisticated, and with virtually no organised crime built around prostitution, gambling, or boot-legging. Even low-level tipping was 
not socially acceptable. The New Zealand Police (formerly called the New Zealand Police Force) was itself almost entirely devoid of the sort of corruption commonly associated with police behaviour in other countries, including New Zealand's trans-Tasman neighbour, Australia (Holmes, 2010).

Unlike Australia, New Zealand has had a unitary system of government since its fledgling provincial governments were abolished in 1876. Like Australia, however, its head of state is the British monarch, and both countries inherited the Westminster model of Parliamentary democracy, though each has developed its own parochial version of that system (Weller, Wanna and Patapan, 2005). New Zealand was a full-fledged member of the 'Old Commonwealth' - along with Britain, Canada, South Africa, and Australia, countries not known for having significant levels of governmental corruption. New Zealand did not acquire formal constitutional independence from Britain until 1947, but in the preceding decades had achieved a great deal of de facto independence.

In this era of nation-building, the passage through Parliament of the Public Service Act of 1912 (coming into force the following year) was a seminal and foundational event. The Act, consistent with developments in other parts of the English-speaking world, established a unified, professional, merit-based public service career system, one that was centrally controlled, and that endured until the radical state sector reforms of the 1980s and 90s. The Act put a stop to the rampant political patronage that had hitherto characterised public service employment in the preceding decades. It laid the foundation for the emergence of a strong public service ethos, which became instilled in employees from the time of their initial recruitment after leaving school or university until their retirement from this essentially closed-shop career 30 or 40 years later. During this time, most employees saw themselves generically and collectively as 'public servants', regardless of the positions they as individuals held, or the roles that they performed. According to Webb (1940: 84), 'Every cadet who enters the service does so in the knowledge that there are no barriers to his [sic] advancement to the highest positions, that his capacities will be impartially 
assessed, that his right of appeal against decisions affecting his status and salary is carefully safeguarded, and that he will be adequately pensioned on his retirement.' Fairness was again a key value. Similarly, as Lipson (1948: 479) argued in his a seminal commentary on New Zealand's egalitarianism, 'there is a commendable absence of graft and a strict code of honesty', attributable in his view to job security, strict accounting and audit requirements, and also to an 'inner check' reflecting public servants' professional commitment to the ideal of the public interest'.

This 'normative model' was in turn strongly reinforced by rigorous controls exercised over government officials, controls which allowed zero tolerance of any form of behaviour that could be defined as corrupt or even unethical. As a leading New Zealand public service practitioner-scholar wrote in the late-1950s:

There seems to be common in New Zealand a notion that the responsibilities and moral obligations of public servants are somehow substantially greater than those of other citizens...If his standard of conduct is more scrupulous - and, in some respects it is - the reason is to be found largely in the self-interest of the public servant. He is subject to more extensive controls than most private citizens: he is more likely to be caught if he commits an indiscretion: his career may suffer even if there is only suspicion of unsatisfactory conduct (Polaschek, 1958: 283).

New Zealand was the first country to introduce the Danish institution of the Ombudsman, in 1962, as a further means of control over executive authority, and it opened up official information to the public in the early 1980s, well before the abolition of the Official Secrets Act in Britain. Albeit heavily controlled, a career in the service of government gave employees secure employment as long as they remained totally non-corrupt, and even if they were only adequately competent.

Nor was the financial grass necessarily greener in the private sector. Security of tenure was not really bought at the cost of substantially lower wages than those available in the private sector. The 'public service discount' was not only generally minimal, but under the 'mildly corporate' system of wage-fixing that characterised New Zealand's industrial relations for several decades, state sector pay rates were often seen to be ahead of those available in private employment (Roberts, $1978)^{4}$ 
However, as Lipson (1948: 481-82) argued, the state in New Zealand was not some external force in the continental European tradition. It was rather the people themselves in action, nationbuilding in pragmatic rather than ideological ways, and only too ready and willing to develop national infrastructure in the absence of commercial competition. In this, public employment was not seen as having one's 'snout in the public trough', and although New Zealand never developed an institutionalised administrative elite like that in Britain, its public service ethos similarly embodied values like honour, duty, decency and a strong sense of the public interest. There was little if any scope or even temptation for corruption in procurement, of the kinds that are commonplace elsewhere. The Department of Public Works, established in 1876, later the Ministry of Works, monopolised such development, and was itself firmly imbued with the high standards of ethical probity than characterised the wider state sector.

This strong normative ethos was greatly reinforced during the years of World War II by the serendipitous convergence into top leadership positions in the New Zealand public service of a group of several highly capable men, all able practitioners of 'the profession of statecraft' (Martin, 1988). One leading public administration scholar has suggested that the period 1940 to 1951 was 'the age of mandarins' in New Zealand government (Martin, 2010). If Ralph Waldo Emerson (1841) believed that 'an institution is the lengthened shadow of one man', then as a institutional whole the New Zealand public service could be seen to embody key values shared by this group of men. They were fully committed to the tacit 'Schafferian Bargain' which shaped the relationship between the political executive and the top levels of the public service (Hood and Lodge, 2006), though the idea of 'serial loyalty' (to successive governments of a different political stripe) on the part of the mandarins was not really tested, as the first Labour Government held office for 14 years, from 1935 to $1949 .{ }^{5}$ Characterising one of these men, as if describing them all, Duff (1941: 95) observed that, 'He is a public servant. With his energy, ability and bold imagination, he could have had a half a dozen careers and made half a dozen reputations. But he entered the public service. He remained in 
the public service. He is the public service ...' The commitment to impartiality and the rule of law in the administration of public policy was very powerful in New Zealand (and remains so). This cohort of outstanding top officials clearly understood that the opposite of impartiality in public office was the use of that office for illegitimate private gain, and through their own behaviour they set standards that became deeply embedded in the culture of New Zealand public service (Gregory, 1999).

Nor was it irrelevant that these public service 'mandarins' lived and worked in the capital city of Wellington, located in the centre of the country, at the foot of the North Island. They would, of course, have made their collective impression in the centre of government, wherever it had been located, but the fact that Wellington had been chosen as the capital city in 1865 by New Zealand's then Governor, Sir George Grey, was a significant factor in the emergence of a largely non-corrupt governmental system. Prior to that choice, from 1841 to 1865 , the capital city had been Auckland, in the north of the North Island. Auckland had always been, as it is today, by far New Zealand's largest city, but it was in those days not only the centre of government, but also a city imbued with the spirit of commercial entrepreneurship and associated 'wheeling and dealing', with money the predominant standard by which success was measured. (This remains largely the case today.) By choosing Wellington as the new capital city, albeit largely for logistical reasons, Governor Grey was also laying the foundation for a capital city whose culture would be shaped by governmental rather than commercial values and institutions, and thus would be less likely-especially in these earlier decades of cultural emergence - to become tainted with corruption.

The year 1865 was squarely in the middle of the New Zealand Wars, previously known as the 'Land Wars,' or the 'Māori Wars,' which were fought from 1845 to 1872 between the forces of the colonial government (the Crown) and many Māori iwi (tribes) (Belich, 1998; King, 2003). They involved the punitive confiscation of large areas of Maori land by the government, in apparent contravention of the country's founding constitutional charter, the Treaty of Waitangi, signed in 
1840 between the Crown and many Māori iwi. More than one hundred and thirty years later, about the mid-1970s, at the beginning of what many have seen as a Māori cultural and political renaissance, the New Zealand government began a process of Treaty Settlements, to provide redress for historical grievances, a process which continues to this day.

This whole issue is raised here because it shows how any consideration of corruption in the history of New Zealand government needs also to be viewed from the perspectives of Māori, who were victims of unjust practices perpetrated by the Crown and its agents mainly in the $19^{\text {th }}$ century, notwithstanding the fact that the early colonial administration in New Zealand had been at pains to deal fairly and honestly with land acquisition and settlement issues. Indeed, it would not be drawing too long a bow to see much of this behaviour by the Crown's agents as a form of 'greed', corruption, even though public officials themselves may not have been the prime beneficiaries. ${ }^{6}$ If corruption as a governmental phenomenon has to be gauged largely by perceptions of its incidence, then it clearly matters as to who is doing the perceiving. Just as 'seeing is believing', so too is the converse the case: 'believing is [not] seeing.' In this connection, it is worth quoting from two of the most acute historical observers of New Zealand society, to help understand why perhaps New Zealanders' national self-image, born of cultural insecurity, has tended to be self-congratulatory rather than self-critical. The French political commentator, André Siegfried, in 1914 published his observations of New Zealand society, wryly noting that, 'Many New Zealanders are honestly convinced that the attention of the whole world is concentrated on them, waiting with curiosity and even with anxiety to see what they will say and do next...they have become so accustomed to being taken seriously that they have become conscious of a mission to humanity' (Siegfried, 1914: 58-59). Writing nearly half a century later, Lipson (1948: 459-60), noted that this attitude was still prevalent. 'The publicity of the government, the press, and a host of private organisations constantly assures the public that New Zealand leads the world in this, that, and the other', he noted. 'So often is the point repeated and asserted about so many features of the Dominion's life that it is 
now earnestly believed by the majority. It is held as a faith which few call in question...Under its worst forms it can degenerate into smugness and complacency, the national delusion of the selfsatisfied.'

\section{A changing picture of corruption in New Zealand}

In New Zealand, legal definitions of what constitutes corruption are narrow and orthodox. 'Bribery and Corruption' as such is covered by two statutes - the Crimes Act 1961, and the Secret Commissions Act 1910. The Crimes Act (Part VI - 'Crimes affecting the administration of law and justice - Bribery and Corruption') provides for prison sentences of up to 14 years for judicial officers and ministers of the Crown, who seek or accept bribes, and of up to seven years for anyone who offers a bribe to them; and sentences of up to seven years for any Member of Parliament, law enforcement officer or bureaucrat who accepts or seeks a bribe, and up to seven years for anyone offering bribes to them or to foreign officials (unless the bribe, offered outside of New Zealand, is not illegal in that other country). An official can receive a sentence of up to seven years in prison for using official information for personal advantage; and anyone who uses or discloses for his or her own advantage personal information illegally supplied by an official is liable for up to seven years in prison. The Secret Commissions Act, which is perhaps mistakenly seen to cover 'private sector' corruption, deals with the secret acceptance of 'valuable considerations' (commissions) by agents unknown to their principals, including such commissions received in the procuring of contracts. The conduct of New Zealanders transacting business overseas is now subject to the provisions of Britain's forceful Bribery Act, which became operational in 2011, and which reflects the international anti-corruption strategies being pursued by organisations such as the World Bank, the International Monetary Fund (IMF), the Asia Development Bank (ADB), the Organisation for Economic Cooperation and Development (OECD), and so on. New Zealand businesses that have 
close dealings with enterprises in countries where corruption is endemic may be more at risk of falling foul of the provisions of this particular piece of legislation.

The penalties under the Secret Commissions Act are currently light, and are now under legislative reconsideration, with the aim of bringing them into line with the bribery and corruption penalties applying under the Crimes Act. Also, Parliament is currently considering extending the corruption provisions in the Crimes Act to cover 'trading in influence' - whereby a public official, in exchange for advantages, undertakes to use his influence to benefit the person who provides the advantages. These initiatives follow governmental consideration of law changes that would be required in New Zealand were Parliament to ratify the United Nations Convention against Corruption (more on this below).

Even before the world financial crisis of 2008, financial fraud had become glaringly apparent in New Zealand. A former head of New Zealand's Serious Fraud Office (SFO) publicly admonished corporate directors for doing too little about 'financial crime and corruption' in their organisations, in the light of a series of high profile convictions of finance company executives following a spate of institutional collapses linked to the international financial crisis of the late 2000s, and involving the loss to investors of hundreds of millions of dollars. He argued that New Zealand is today socially, ethnically and financially_ 'in terms of rich and poor in our society' — a 'very different country than we were a few years ago and, particularly since the global financial crisis' (Birchfield, 2012). The former director dismissed the value of the CPI's rating of New Zealand: in his view, company directors and legislators were sweeping the country's growing crime and corruption problem under the board table.' In support of his arguments, he cited the results of an SFO survey, which indicated that a majority of New Zealanders did not share the CPI's view of corruption in their country: only $37 \%$ of respondents believed that the country was 'largely free' of serious fraud and corruption. At the height of the share market boom before the October $1987 \mathrm{crash}$, illegal and dodgy commercial practices were rife. According to Bruce Jesson (1999: 126), 'Not only did the 
ethical standards of business collapse during the share market boom, but so also did the notion that there should even be ethical standards...'

A Price Waterhouse Cooper/Office of the Auditor-General (2011) survey of fraud and corruption in New Zealand organisations of various sizes found that such events in the previous two years, with a cost of more than $\$ 100,000$, were reported by up to eight percent of respondents. Fraud and/or corruption events in the previous two years, with a cost of between $\$ 10,000$ and $\$ 100,000$, were reported by up to 9.5 percent of those surveyed. A KPMG survey in 2012 of fraud, bribery and corruption in Australia and New Zealand, while not providing separate data on each country, found that 'almost three-quarters of respondents reported that their organisation has experienced behaviours that are defined as bribery or corruption' (KPMG, 2013: 34). Moreover, while perpetrators of fraud were more likely to be non-management employees, a 'real concern' was that fraud committed by senior executives and company directors had doubled since 2006 (KPMG, 2013: 9). The study also found that more than half of the respondents indicated that their organisations did not perform active monitoring of bribery and corruption payments. There is no central clearing house for information about the prosecution and conviction of New Zealand public officials on corruption or fraud charges, but some casual research only between 2001 and 2005 uncovered a not insubstantial list (Gregory, Zirker and Scrimgeour, 2012: 14-15; Gregory, 2002, 2006. See Appendix. It can also be noted in this connection that New Zealand has no common law offence of 'Misconduct in Public Office', such as exists in Hong Kong.)

More needs to be known about how New Zealanders perceive activities that could be called corrupt. Taito Philip Field, a Samoan New Zealander who became the first New Zealand MP to be convicted and imprisoned for corruption, claimed at his trial in 2009 that New Zealanders did not understand the time-honoured Pacific tradition of gift-giving. The Supreme Court, which unanimously rejected his appeal, said that any gift-giving to officials with the power to influence a relevant case represented corruption. ${ }^{7}$ The then head of New Zealand's immigration service, Mary 
Anne Thompson, was seen to have practised nepotism in 2008, in attempting to gain residency to New Zealand for some of her Pacific Island extended family members. She also pleaded guilty to having falsely claimed to have received a doctorate from the London School of Economics and Political Science (Gregory, 2009). Donna Awatere Huata, an MP at the time of committing her offences, was sentenced in 2005 to 33 months in jail for stealing from a Māori trust set up to help under-privileged children, and for perverting the course of justice. In 2011, a former Accident Compensation Corporation (ACC) National Property Manager was convicted on charges of corruption while in office and sentenced to eleven months of home detention. In recent years, there have been several cases of MPs 'double-dipping' on accommodation allowances, and exorbitant uses of travel allowances. After public scrutiny the Deputy Prime Minister, Bill English, repaid \$12,000 worth of housing allowances. These public controversies are New Zealand's milder version of the much larger frauds perpetrated on British taxpayers in recent years by several Westminster MPs. While not comparable in scope or size to the most egregious cases that were uncovered in Britain, they do not help to sustain public trust in New Zealand's politicians. Commenting on practices that were commonplace in the late 1990s, criminologist Greg Newbold (2000: 42) observed that, 'The squandering of millions of dollars by politicians and public servants through expensive trips abroad, golden handshakes and opulent conferences is now well known.'

In 2000 the then State Services Commissioner argued that there were two countervailing pressures against New Zealand's record of honesty in the public sector. The first related to documents of national identity and residents' permits, and their importance to an increasing level of Asian-based international organised crime activity in the Pacific region. In his words:

... since the end of the Cold War there has been an increase in both political instability and international criminal activity in our region. International organised crime based in Asia is having an impact in the Pacific, including in New Zealand. Documents of national identity and residents' permits have a particular value in this milieu. The criminals have large sums at their disposal. The sums of money that can be offered to officials are very large compared with officials' annual salaries (State Services Commission 2000: 3-4). 
The second risk factor, according to the Commissioner, was the fact that personal information had become 'a marketable and valuable commodity'.

\section{Corruption issues and reputational risks in New Zealand}

The relationship between corruption and national reputation in countries with a free press is typically mediated by the national news media. New Zealand's impressive successes in combatting corruption, retaining its CPI status as the perceived least corrupt country in the world, and as the best place to do business, ${ }^{8}$ as well as a veritable parade of other impressive rankings and awards, are ceremonially and repeatedly recorded in the country's news media. Nevertheless, dire warnings of the 'slippery slope' of corruption, and the need for 'more transparency', also figure prominently, occasionally in the same reports. ${ }^{9}$ It is clear that New Zealanders have a lot to lose, although repeated sterling non-corruption rankings lead to complacency, and represent a potential disincentive to anti-corruption policy-making, and vigilance in defence against corruption. Even as national corruption scandals, 'loopholes' in New Zealand's legislation, the apparent growth of organised crime, and, perhaps — most threatening of all — the rapid growth of income inequality in New Zealand, make their way into headlines, New Zealand's international reputation seems to prosper. How long will this last?

Corruption scandals have increased exponentially in the last five years, at least in their coverage in New Zealand's media. The most prominent recent example of these followed the New Zealand Police arrest (in concert with the American FBI) of Kim Dotcom, a multi-millionaire German internet site operator with a shady past, residing in New Zealand and accused of massive copyright violations through his 'Mega Upload' site, which at one point accounted for nearly five percent of the world's internet traffic. Dotcom (his name changed legally to reflect his occupation) seems to have had special support in his successful bid for New Zealand residency. ${ }^{10}$ Soon after his 
arrest he announced that a member of the ruling National Party coalition, John Banks - the only Association of Consumers and Taxpayers (ACT) MP in the House of Representatives, had accepted an 'illegally anonymous’ $\$ 50,000$ campaign donation from him during his (Banks') unsuccessful 2010 Auckland mayoral campaign. ${ }^{11}$ The rules are clear on this: if a candidate knows the source of a major campaign donation, it must be listed by source, not as 'anonymous,'as Dotcom's had been. A number of candidates, including Bank's former rival in the 2011 Parliamentary election (as head of the new Conservative Party), Colin Craig, have expressed outrage at this 'corrupt behaviour,' and are moving to replace Banks at the first opportunity. ${ }^{12}$ In any event, both Banks' and New Zealand's reputations were threatened by this, with the New Zealand Police investigating alleged campaign violations ${ }^{13}$ before deciding, on apparently shaky grounds, not to press charges. ${ }^{14}$

It is beyond the scope of this paper to list all of the recent corruption scandals that pose reputational risks to New Zealand. Suffice it to say that there has been a series of scandals of various kinds involving prison guards, police officers, and former and current officials (including a former Minister of Justice) involved with allegedly fraudulent investment schemes, and so on, some of which are listed in the Appendix. While it can be argued that the public prosecution of such cases is in keeping with New Zealand's corruption-free reputation, the recently reported growth of organised crime in New Zealand, sometimes linked to the Chinese Triads and other groups involved in illegal drug manufacturing and distribution, has the potential to sully this reputation. In this context, the apparent reluctance of New Zealand to ratify (after signing in 2003) the United Nations Convention against Corruption (UNCaC), which would compel major public officials and their families to maintain full financial transparency, and the belated passage of the Anti-Money Laundering and Countering Financing of Terrorism Act (Public Act 2009 No. 35, which only went fully into effect in 2013), suggest a degree of inertia in New Zealand's defence of its clean, green image. ${ }^{15}$ Regarding the latter, anti-money laundering legislation has been at the forefront of worldwide anti-corruption efforts over the past several decades, but New Zealand's belated adoption of 
this legislation required extraordinary training of local firms, ${ }^{16}$ most of which have been engaged in high levels of foreign trade, apparently without formal/legal observation of international legal norms in combatting corruption. ${ }^{17}$ There is little doubt that the Anti-Money Laundering Act, as it is gradually implemented, will have a major remediating impact in this previously grey area of New Zealand's global financial linkages.

Revelations in 2012 that a loophole in New Zealand's trust laws allows off-shore parties with no legal connection to New Zealand to establish tax-free trust havens suggest a further challenge to the country's non-corrupt reputation. ${ }^{18}$ As an intermediary for Cayman Islands-style banking secrecy, it is increasingly presumed that New Zealand is indirectly benefitting through its trust system from global financial malfeasance, at least some of which is certain to be corruption.

A recent Bill before the House to control the worst excesses of Parliamentary 'lobbying' underscores yet another risk to New Zealand's non-corrupt reputation. ${ }^{19}$ Largely uncontrolled lobbying in Parliament has increasingly been reported in the news media as a growing problem that is often linked to corruption. Efforts to regulate lobbying have encountered significant resistance, ${ }^{20}$ raising further doubts about the authenticity of New Zealand's reputation. ${ }^{21}$ Open access to the nation's MPs has long been seen as a hallmark of New Zealand's vibrant democracy. Lobbyists have quickly come to represent a direct threat to the country's non-corrupt reputation, and thus to its democratic tradition.

Arguably, the most corrosive change in New Zealand society is the marked growth in income inequality that has beset the country since the neo-liberalisation of the state, beginning in 1988 , and its impact upon a putative growth in corrupt tendencies. As news reports noted in 2011 and 2012, the gap between the rich and the poor has increased more than in any other OECD country over the past two decades, on top of a widening gap in all other OECD countries. ${ }^{22}$ A recent Salvation Army report stresses this, arguing that increasing numbers of New Zealanders had been marginalised in the last two years. ${ }^{23}$ This manifests itself immediately in the well-being (or lack thereof) of children, 
${ }^{24}$ and in deteriorating race relations. ${ }^{25}$ With the wealthiest one per cent of the population now owning three times more than 'the combined cash and assets of the poorest 50 per cent', ${ }^{26}$ the presumption is that increasing crime, including corruption, and even a surge in some diseases, might result. ${ }^{27}$

Probably the most aggressive current assault on New Zealand's non-corrupt reputation is materialising in the city of Christchurch's rebuilding project, following the destructive earthquakes of 4 September 2010, and 22 February 2011. Despite explicit warnings in the national media of the potential for fraud and corruption in the multi-billion dollar rebuilding project, ${ }^{28}$ contractors using public funds have made significant use of illegal migrants, paying miniscule wages, and in violation of visa restrictions. ${ }^{29}$ Another alleged fraud, worth 'billions of dollars', was reported in the national media to be under investigation by the Serious Fraud Office in late 2012. ${ }^{30}$

\section{Conclusion}

In providing a set of largely narrative reasons as to why New Zealand has for a very long time been a country without significant levels of governmental and other corruption, and while suggesting that the country's top ranking on the CPI does not tell the full, or even the most interesting story, we do not mean to imply that all of a sudden corruption is becoming a major problem in New Zealand. Rather, we argue that there are significant recent signs that it is becoming an issue of increasing, if still little recognised, public importance, and that the country's strong international reputation may warrant closer scrutiny. While recent evidence may go nowhere near indicating that corruption in New Zealand may grow to a scale comparable to that in many other countries, nevertheless, if New Zealanders are genuinely concerned to maintain the standards they have been accustomed to in the past, then more public policy attention may soon need to be given to this complex and difficult issue. 


\section{Appendix}

1. An Immigration Department officer pleaded guilty to accepting $\$ 100,000$ in bribes to secure permanent residency for Korean immigrants and was jailed for two-and-a-half years.

2. A Housing New Zealand employee was jailed for accepting bribes amounting to $\$ 60,000$.

3. A Department of Conservation senior manager was jailed for defrauding his department of $\$ 180,000$.

4. A case manager with the former Department of Work and Income (DWI) was imprisoned for selling confidential beneficiary information to a repossession agent and for stealing more than $\$ 30,000$ from the department.

5. A senior property manager for the same department was jailed for three years after receiving nearly $\$ 640,000$ in bribes.

6. Another official of this department pleaded guilty to 32 charges of misappropriation totalling more than $\$ 30,000$.

7. In March 2002 yet another employee of DWI, who had worked for the department for 16 years, was jailed for defrauding the agency of more than $\$ 81,000$.

8. A Customs Service official was jailed after pleading guilty to bribery and fraud charges involving the importation of luxury stolen cars.

9. An official with the Ministry of Economic Development was jailed for 18 months for using official information to set up his own business.

10. A clerk in the same ministry was convicted of stealing more than $\$ 25,000$ from her employer.

11. A Fire Service national commander resigned after an internal investigation found he had spent 'a significant amount' of public money on family travel and private international phone calls.

12. A Customs Service officer sentenced to nine years in jail for his involvement in drug smuggling by organised crime.

13. An Inland Revenue Department (IRD) officer pleaded guilty to six charges of failing to maintain the secrecy of taxpayers' and the department's information.

14. Another IRD officer was jailed for selling taxpayers' details to debt collectors.

15. A ministerial secretary was convicted for her part in passing on confidential Inland Revenue Department information to a family member chasing a debt.

16. Forty-three staff of the Ministry of Social Development were caught committing fraud totalling $\$ 729,442$ during $2000-2003$.

17. An Immigration Service official was sacked after requesting sexual favours from a woman applicant.

18. An Immigration Service worker charged with stealing from foreigners in the course of his work faces seven years' jail if found guilty (case pending).

19. In a very high profile case, a manager in the Ministry of Social Development was jailed for five and ahalf years for defrauding the agency of $\$ 1.9$ million over a period of 28 months, and for receiving a benefit while working full-time in the organisation.

Earlier in the 1990s, the Executive Director of New Zealand's Sports Foundation was imprisoned for stealing over \$1 million from the organisation; a former railways consultant was sent to jail for defrauding New Zealand Railways of \$46,000; a commercial manager of the Electricity Corporation of New Zealand, was jailed for defrauding the organisation of \$1.1million; and a former Controller and Auditor-General himself was jailed for defrauding the public purse of about $\$ 56,000$ while in office. 


\section{References}

Bassett, Michael and King, Michael (2000) Tomorrow Comes the Song: A Life of Peter Fraser, Auckland: Penguin.

Bauhr, Monika and Nasiritousi, Nagmeh (2011) 'Why Pay Bribes? Collective Action and Anti-Corruption Efforts', Working Paper Series 2011: 18, The Quality of Government Institute, University of Gothenburg, Gothenburg.

Belich, James (1998) The New Zealand Wars and the Victorian Interpretation of Racial Conflict, Auckland: Penguin.

Birchfield, Reg (2012) 'Cover Story: Boards Blasé About Management', New Zealand Management, September. http://www.management.co.nz/Editorial.asp?eID $=61744 \& W c a t=7$

Cardona, Francisco (2013) Spain: Corruption, Weak Institutionalization, Unfinished Democratization, Public Administration Review, 73 (1): 95-96.

Duff, Oliver (1941) New Zealand Now, Wellington: Department of Internal Affairs.

Emerson, Ralph Waldo (1841) Self-Reliance, Hoboken NJ: BiblioBytes (electronic).

Esping-Andersen, Gosta (1990) The Three Worlds of Welfare Capitalism, Princeton NJ: Princeton University Press.

Fischer, David (2012) Fairness and Freedom: A History of Two Open Societies: New Zealand and the United States, New York: Oxford University Press.

Galtung, Fredrik (2006) 'Measuring the Immeasurable: Boundaries and Functions of (Macro) Corruption Indices', in Charles Sampford et al (eds) Measuring Corruption, Aldershot UK: Ashgate.

Gregory, Robert (1999) 'Social Capital Theory and Administrative Reform: Maintaining Ethical Probity in Public Service’, Public Administration Review, 59 (1): 63-75.

Gregory, Robert (2002) 'Governmental Corruption in New Zealand: A View Through Nelson's Telescope?' Asian Journal of Political Science, 10 (1): 17-36.

Gregory, Robert (2003) 'New Zealand - The End of Egalitarianism?' in Christopher Hood and B. Guy Peters, with Grace Lee (eds), Reward for High Public Office: Asian and Pacific Rim States, London: Routledge.

Gregory, Robert (2006) 'Governmental Corruption and Social Change in New Zealand: Using Scenarios, 1950-2020’, Asian Journal of Political Science, 14 (2): 117-139.

Gregory, Robert (2009) 'No Suspicious Circumstances? Contractualism and Reputation-Protection in Political-Bureaucratic Relations - The Case of New Zealand Immigration', in Paul Roness and Harald Sætren (eds) Change and Continuity in Public Sector Organisations: Essays in Honour of Per Laegreid, Bergen: Fagbokforlaget.

Gregory, Robert, Zirker, Dan and Scrimgeour, Frank (2012) 'A Kiwi Halo? Defining and Assessing Corruption in a "Non-Corrupt" System', Asia Pacific Journal of Public Administration, 34(1): 1-29.

Griffin, James (1990) Wren, John (1871-1953), Australian Dictionary of Biography, 12, Melbourne: Melbourne University Press. 
Griffin, James (2004) John Wren: A Life Reconsidered, Melbourne: Scribe.

Holmes, Leslie (2010) 'Australian Police Corruption in Comparative Perspective', paper delivered to the $58^{\text {th }}$ annual conference of the Australian Political Studies Association, University of Melbourne, 26-29 September.

Hood, Christopher and Lodge, Martin (2006) The Politics of Public Service Bargains: Reward, Competency, Loyalty - And Blame, New York: Oxford University Press.

Jesson, Bruce (1999) Only Their Purpose Is Mad, Palmerston North: The Dunmore Press.

King, Michael (2003) New Zealanders at War, Auckland: Penguin.

KPMG (2013) A Survey of Fraud, Bribery and Corruption in Australia \& New Zealand 2012. Available at: http://www.kpmg.com/au/en/issuesandinsights/articlespublications/fraud-survey/pages/fraudbribery-corruption-survey-2012.aspx?chan=story1

Lipson, Leslie (1948) The Politics of Equality: New Zealand's Adventures in Democracy, Chicago: University of Chicago Press.

Martin, John (1988) A Profession of Statecraft? Three Essays on Some Current Issues in the New Zealand Public Service, Wellington: Victoria University Institute of Policy Studies.

Martin, John (2010) 'The Age of the Mandarins? Government in New Zealand 1940-51', paper presented to a conference, The Seven Dwarfs and the Age of the Mandarins: Australian Government Administration 1940s to 60s, Australian National University, Canberra, 3 November.

Newbold, Greg (2000) Crime in New Zealand, Palmerston North: Dunmore Press.

Polaschek, Ray (1958) Government Administration in New Zealand, London: Oxford University Press.

PricewaterhouseCoopers/Office of the Auditor-General New Zealand (2011) Global Economic Crime Survey: New Zealand Results, Wellington: Office of the Auditor-General.

Quah, Jon (2003) Curbing Corruption in Asia: A Comparative Study of Six Countries. Singapore: Eastern Universities Press.

Quah, Jon (2010) Curbing Corruption in Asian Countries: The Difference Between Success and Failure, paper presented at the Fourth International Conference on 'Public Management in the $21^{\text {st }}$ Century: Opportunities and Challenges', Macau SAR, 22-23 October.

Quah, Jon (2011) Curbing Corruption in Asian Countries: An Impossible Dream? Bingley, UK: Emerald Group Publishing.

Roberts, John (1978) 'Society and its Politics', in Ian Wards (ed), Thirteen Facets: The Silver Jubilee Essays Surveying the New Elizabethan Age, a Period of Unprecedented Change, Wellington: Government Printer.

Siegfried, André (1914) Democracy in New Zealand, translated from the French by E V Burns, London: Bell.

State Services Commission (2000) Annual Report of the State Services Commission for the Year Ended 30 June 2000, Wellington: New Zealand State Services Commission. 
Sutch, William (1969) Poverty and Progress in New Zealand: A Reassessment, Wellington: Reed.

Temple, Philip (2002) A Sort of Conscience: The Wakefields, Auckland: Auckland University Press.

Webb, Leicester (1940) Government in New Zealand, Wellington: Department of Internal Affairs.

Weller, Patrick, Wanna, John and Patapan, Haig (eds) (2005) Westminster Legacies: Democracy and Responsible Government in Asia and the Pacific, Sydney: University of New South Wales Press.

Zirker, Dan, Gregory, Robert and Scrimgeour, Frank (2012), 'Iceland Agonistes and a Kiwi Halo:

Comparative Perceptions of Corruption and the Rapid Descent of a Leading "Non-Corrupt" Country, 2005-2012', paper delivered to the annual New Zealand Political Studies Association annual conference, Wellington, November 28-30.

\section{Notes}

\footnotetext{
1 The Australian and New Zealand Army Corps (ANZAC) was an expeditionary force that fought in the First World War's Battle of Gallipoli in 1915.

2 New Zealand's welfare state developed more along the lines of the British 'model' rather than the more strongly social-democratic Scandinavian one. See Esping-Andersen (1990).

3 http://en.wikipedia.org/wiki/List of countries by income equality

4 In this system, which endured until the radical reforms of the $1980 \mathrm{~s}$ and $90 \mathrm{~s}$, the government held the ring in negotiations among the three dominant pressure groups - the Federation of Labour, the Employers' Federation, and Federated Farmers.
}

${ }^{5}$ Essentially, the terms of this tacit bargain are that the political executive will forego involvement in the recruitment and promotion of public servants, who in turn will forego some political rights in return for security of employment and dutiful loyalty to the government of the day.

${ }^{6}$ See Bauhr and Nasiritousi (2011). 'Greed' corruption refers to actions of political and bureaucratic grandees who greedily capture state assets by virtue of their high positions in government. 'Need' corruption is engaged in by middle and lower-level officials who pettily seek to enhance their income by exploiting the discretionary authority they are able to exercise over citizens with whom they directly transact.

7 An MP for 15 years, Field was sentenced to six years in jail.

${ }^{8}$ See: Ben Chapman Smith and Hamish Fletcher (2012) 'NZ Ranked Best in World to Do Business', New Zealand Herald, 16/11/2012: http://www.nzherald.co.nz/business/news/article.cfm?c id=3\&objectid=10847700, accessed 08/02/2013.

9 'Editorial: The time has come for more transparency', The New Zealand Herald, 11/04/2012.

${ }^{10}$ The Dotcom scandal is sometimes portrayed in the media as representing a major threat to New Zealand's noncorrupt reputation. 'Editorial: Kim Dotcom sets off year of fireworks for politicians', New Zealand Herald, 27/12/2012.

${ }^{11}$ It was listed as anonymous, and Banks has said that he was unaware of its source despite Dotcom's frequent testimony to the contrary.

${ }^{12}$ Fairfax NZ News, 'Colin Craig and John Banks Compared', 08/05/2012: www.stuff.co.nz/national/politics/6877074/Colin-Craig-And-John-Banks-Compared, accessed 08/02/2013.

${ }^{13}$ John Hartevelt (2012) 'Widening Banks Campaign Donations Probe', Fairfax NZ News, 30/04/2012: www.stuff.co.nz/national/politics/6826949/Widening-Banks-campaign-donations-probe, accessed 08/02/2013.

${ }^{14}$ Police found that Banks did solicit the donations but didn't have enough evidence under current legislation to charge him, specifically, that 'they could not establish Banks had the necessary knowledge that a $\$ 15,000$ donation from SkyCity was recorded as anonymous before he signed and submitted his return. They made the same finding about anonymous radio advertisements worth $\$ 15,690$ and two \$25,000 donations from internet million Kim Dotcom.' Fairfax News NZ 2012, 'Banks won't be charged, police say', Fairfax News NZ, 26/07/2012:

http://www.stuff.co.nz/national/politics/7353754/Banks-won-t-be-charged-police-say .

${ }^{15} \mathrm{http}$ ://www.legislation.govt.nz/act/public/2009/latest/DLM2140720.html, accessed 08/02/2013.

${ }^{16}$ For example, barristers Wilson and Harle in Auckland launched a website in 2010 to begin training corporate executives in the nuances of the new bill. As the website notes, 'A long-awaited upgrade of New Zealand's Anti-Money Laundering (AML) law was finally passed by Parliament late last year. But although this is one of the most farreaching pieces of law reform to hit the financial sector in recent years, it remains an over-arching framework only - it is not yet properly in force, and a lot of specific detail is still to be developed for particular sectors via subsidiary 
regulations and guidelines. Now the "rubber" is starting to hit the road, with the Ministry of Justice starting to develop those details in a consultation paper covering the specific AML regime likely to apply to regulated "reporting entities". The Ministry and the other supervising agencies are keen "to test some initial thinking with industry" on the matters that will find their way into the detailed aspects of the regime: the regulations, codes of practice and guidelines that will flesh out the bare bones of the Anti-Money Laundering and Countering Financing of Terrorism Act 2009 (AML/CFT Act). This article recaps the essentials of New Zealand's new AML framework, and then examines some key aspects of the Ministry's detailed proposals, which are available at www.justice.govt.nz . Submissions can be made by 19 March 2010'. http://www.wilsonharle.com/new-zealand-s-anti-money-laundering-law-now-the-rubber-hits-the-road/ , accessed 10/02/2013.

${ }^{17}$ It is difficult to avoid the central importance of this fight against the most extreme forms of corruption. The British Bank, HSCB, for example, agreed in December of 2012 to pay nearly \$2 billion to US authorities after admitting to laundering at least $\$ 881$ million in drug trafficking money in a case that received close attention in the New Zealand media. The New Zealand Herald described it as 'the latest scandal to hit banks since the financial crisis started in 2008. Standard Chartered PLC, another British bank, signed an agreement with New York regulators on Monday to settle a money-laundering investigation involving Iran with a \$340 million payment.' APN 2012, 'HSCB to pay \$1.9b to settle money-laundering case', New Zealand Herald, 12/12/2012.

${ }^{18}$ A recent New Zealand TV-3 exposé underscored the use of New Zealand trust laws to establish anonymous tax-free trusts for off-shore interests: http://www.tv3.co.nz/October-7th---Treasure-

Islands/tabid/2059/articleID/79738/Default.aspx Accessed 08/02/2013.

${ }^{19}$ Adam Dudding (2011) 'Inside political lobbying', Fairfax NZ News, 17/07/2011: www.stuff.co.nz/national/politics/5297632/Inside-political-lobbying, accessed 08/02/2013.

${ }^{20}$ John Hartevelt (2012) 'Lobbyists push back against bill', Fairfax NZ News, 25/10/2012: www.stuff.co.nz/national/politics/7859944/Lobbyists-push-back-against-bill, accessed 08/02/2013; in an editorial in the Dominion Post, a constitutional lawyer stridently criticised the bill, arguing that the bill is badly drafted and would distance MPs from 'the people': Jordan Williams 2012, 'Lobbying bill will distance people from MPs', Dominion Post, 21/09/2012: www.stuff.co.nz/dominion-post/7708988/Lobbying-bill-will-distance-people-from-MPs , accessed $08 / 02 / 2013$.

${ }^{21}$ Dudding (above) quotes the late Jeremy Pope in his article. Pope, a New Zealander and one of the founders of Transparency International, argued that the lack of transparency in New Zealand, and particularly in such activities as lobbying, was 'an accident waiting to happen. No one knows how many there are and who they're lobbying for and who they're lobbying to'. www.stuff.co.nz/national/politics/5297632/Inside-political-lobbying, accessed 08/02/2013. ${ }^{22}$ Kirsty Johnston (2011) 'New Zealand's Wealth Gap Widens', Dominion Post, 06/12/2011: www.stuff.co.nz/dominion-post/news/6092339/New-Zealands-wealth-gap-widens , accessed 08/02/2013; Gordon Campbell (2011) 'Putting the Focus on Income Inequality', The Wellingtonian, 11/08/2011:

www.stuff.co.nz/dominion-post/news/local-papers/the-wellingtonian/opinion/5423125/Putting-the-focus-on-incomeinequality, accessed 08/02/2013. Campbell observes that the 10 wealthiest New Zealanders own approximately 11 per cent of the country's GDP, while the 10 wealthiest Australians own just over 4 per cent of the Australian GDP; Michelle Cooke (2012) 'Poor Get Poorer, inequality reigns-survey', Fairfax NZ News, 23/08/2012: www.stuff.co.nz/national/politics/7536914/Poor-get-poorer-inequality-reigns-survey, accessed 08/02/2013. Cooke notes that New Zealand household incomes declined by three percent between July 2010 and June 2011, that the incomes of the lowest decile declined markedly, while the incomes of the top deciles increased, and that 21 per cent of New Zealand children now live in poverty, again a marked change over the past decade.

${ }^{23}$ Kate Chapman (2013) 'Poor Kiwis left behind, says Salvation Army', Fairfax NZ News, 13/02/2013: http://www.stuff.co.nz/national/8295161/Poor-Kiwis-left-behind-says-Salvation-Army .

${ }^{24}$ Michelle Duff and Andrew Board (2010) “"Shameful record” as Kiwi kids suffer', Fairfax NZ News, 06/12/2010: www.stuff.co.nz/national/4425416/Shameful-record-as-Kiwi-kids-suffer, accessed 08/02/2013. Duff and Board note, for example, that New Zealand has the second worst record for child safety among 30 developed countries, and that child abuse and gang violence are natural extensions of this development.

25 'Racial prejudice, inequality "still entrenched in NZ", Dominion Post, 08/03/2012: www.stuff.co.nz/dominionpost/news/6541003/Racial-prejudice-inequality-still-entrenched-in-NZ , accessed 08/02/2013.

${ }^{26}$ Lane Nichols (2011) 'Revealing the gap between NZ's rich and poor', Fairfax NZ News, 18/11/2011: www.stuff.co.nz/national/politics/5989843/Revealing-the-gap-between NZs-rich-and-poor, accessed 08/02/2013.

${ }^{27}$ Clio Francis (2012) 'Surge in disease blamed on social inequality', Dominion Post, 20/02/2012: www.stuff.co.nz/dominion-post/news/6448733/Surge-in-disease-blamed-on-social-inequality, accessed 08/02/2013.

${ }^{28}$ Maria Slade (2012) 'Lax Kiwi systems “open to bribery"', Fairfax NZ News, 13/09/2012: www.stuff.co.nz/business/rebuilding-christchurch/7664577/Lax-Kiwi-systems-open-to-bribery, accessed 08/02/2013; Richard Meadows (2012) 'Huge fraud potential in Chch rebuild', Fairfax NZ News, 18/09/2012: www.stuff.co.nz/business/rebuilding-christchurch/7696127/Huge-fraud-potential-in-Chch-rebuild, accessed 
08/02/2013; 'Editorial: Vigilance needed during rebuild', The Press 24/10/2012: www.stuff.co.nz/thepress/opinion/editorials/7854624/Editorial-Vigilance-needed-during-rebuild, accessed 08/02/2013. ${ }^{29}$ Olivia Carville (2013) ‘Quake rebuild sparks job scam', Fairfax NZ News, 13/01/2013: www.stuff.co.nz/national/christchurch-earthquake/8171833/Quake-rebuild-sparks-job-scam, accessed 08/02/2013 ${ }^{30}$ Alan Wood (2012) 'Monster Christchurch rebuild fraud feared', Fairfax NZ News, 28/09/2012: www.stuff.co.nz/business/rebuilding-christchurch/7740372/Monster-Christchurch-rebuild-fraud-feared , accessed $08 / 02 / 2013$. 